\title{
Prognostic Value of Serum Lactate Levels in Critically Ill Patients in an Intensive Care Unit
}

\author{
Hedgar Berty Gutiérrez*, Yenisey Arteaga Concepción, Jorge Soneira Pérez, Yanín Díaz \\ Lara, Félix Mario Rivero López, Pedro Rosales Contreras \\ Miguel Enríquez hospital, La Habana, Cuba
}

\begin{abstract}
Introduction: The patient in critical condition, regardless of the cause of admission, continues to be a challenge for health systems due to the high mortality that it reports. There is a need to identify some marker of early obtaining, easy to interpret and with high relevance in the prognosis of these patients. Objective: To determine the prognostic value of serum lactate in an Intensive Care Unit (ICU). Method: One hundred and forty-five patients admitted to an ICU were enrolled in the study. The Acute Physiology and Chronic Health Evaluation II (APACHE) prognosis score, Sequential Organ Failure Assessment, hemodynamic support need, mechanical ventilation, cause of admission, stay in ICU, analytical and physiological variables were determined. The probability of survival of patients who had elevated and normal serum lactate levels was calculated. The risk of dying was determined using the Cox regression model. Results: Twenty-eight patients died (19\%) in the ICU. The serum lactate value was higher in the group of patients with trauma, infections, APACHE II and high creatinine levels; as well as with decreased mean arterial blood pressure, need for hemodynamic support and mechanical ventilation. The survival capacity was higher in patients who had normal serum lactate. Serum lactate was the sole independent predictor of mortality (AHR 1.28 [1.07-1.53], $p=$ 0.008). Conclusions: Patient assessment through the determination of serum lactate levels provides useful information in the initial evaluation of the critical patient.
\end{abstract}

Keywords: serum lactate, prognosis, intensive care unit, hyperlactatemia, APACHE

Received: 18 November 2019 / Accepted: 29 January 2020

\section{INTRODUCTION}

The seriously ill patient is currently a challenge for both the medical staff and the health system, given its complexity and variability. New strategies and therapies to reduce mortality, hospitalization time, sequelae and costs are required [1].

Severity indexes or prognostic scales are necessary methods to estimate the severity of anatomical lesions, physiological alterations and the probability of survival of the patients. Validation of these indices has allowed their widespread use and the adoption of a universal language on the subject [2].

There are different scales to assess the clinical status of a patient, which allow a diagnosis of the existing severity and which help anticipate possible imminent and late complications, including death [3].

For several years the use of a predictor of organic dysfunction in critically ill patients (CIP) has been pro- posed, recommending that the ideal should meet the criteria in the context of critical care, be simple, routinely reproducible and promptly evaluable [3].

Serum lactate levels can be a useful tool in confirming tissue hypoperfusion and organic dysfunction. Knowledge of this marker allows the establishment of values that allow an early indication of the severity of the patient's clinical condition and the ability to monitor the progression of the critical situation, thus impacting on the patient's prognosis and possibly reducing mortality $[4,5]$.

According to the published literature, multiple studies relate the serum lactate levels in patients with septic [6] and polytraumatized states [7], but data concerning the general context of intensive care remain scarce.

The objective of this study is to determine the prognostic value of serum lactate in patients admitted to the ICU. 


\section{MATERIALS AND METHODS}

\section{Design}

A cohort, observational, prospective study was carried out in the Intensive Care Unit (ICU) of the General Hospital, Havana, Cuba between October 1, 2016, and October 1, 2017. The study was approved by the hospital's Scientific Council and the Ethics Committee. Prior to data collection, written informed consent was obtained from patients and family members.

\section{Patients}

All patients older than 18 years who presented with manifestations of tissue hypoperfusion, such as arterial hypotension, oliguria, sensory abnormalities, skin temperature gradient and delayed capillary filling time, were included. Complementary studies were performed and different physiological variables were recorded within the first 6 hours after admission to the ICU. Two samples were taken, one at admission to the ICU and another at 6 hours after the initial resuscitation, the averages of serum lactate and all the analytical values and physiological variables that were measured during the study were calculated. Patients with incomplete medical records in the database and those subjects who did not undergo serum lactate determination within the established time period were excluded.

\section{Data collection}

From the ICU database, the following variables were taken at admission: age, sex, prognostic score Acute Physiology and Chronic Health Evaluation II (APACHE II), Sequential Organ Failure Assessment (SOFA), need for hemodynamic support, mechanical ventilation, cause of admission, stay in the ICU, analytical values and physiological variables. The analytical values evaluated were: Leukocytes, hematocrit, platelet count, serum creatinine, arterial blood gas, sodium and potassium. While the physiological variables measured were: Heart rate, respiratory rate and medium arterial tension. The response variable was global mortality in ICU.

The population was divided into two groups, depending on serum lactate levels; Group 1 with $>2 \mathrm{mmol}$ / l-high and Group2 with $\leq 2 \mathrm{mmol}$ / l-normal.

\section{Statistical analysis}

For all the variables, summary measures were used, the qualitative ones were expressed by absolute numbers and percentage. The quantitative ones as the mean(SD) or the median with $25-75 \%$ interquartile range (IQR) according to the distribution of normality of the population. Comparison between the study groups was performed using the Chi-square test $\left(\chi^{2}\right)$ or Fisher's exact test. For the quantitative variables, the Mann-Whitney $\mathrm{U}$ test was used. The Kaplan-Meier method was used to estimate the survival probability of patients admitted to the ICU and the Log-Rank statistic to determine the difference between patients with and without elevated serum lactate levels and the occurrence of the event. The Cox proportional hazard model with adjusting hazard ratio (AHR) and 95\% confidence interval (CI) was used. Statistical tests were considered significant at a two-sided p-value less than 0.05. Statistical analysis was carried out using the $\mathrm{IBM}^{\circledR} \mathrm{SPSS}^{\circledast}$ program, version 23 (Chicago, IL, USA).

\section{DESULTS}

During the study period, 170 patients were admitted to the ICU, of which 15 patients were excluded because they did not present serum lactate level determinations in the first six hours after admission and a further twenty due to incomplete clinical records in the database. A total of 145 subjects were enrolled in the study (85\%)of which twenty-eight died in the ICU (19\%).

The general characteristics of the population studied, stratified according to serum lactate levels in the first six hours after admission to the ICU are shown in (Table 1). Traumatic $(\mathrm{p}=0.05)$ and infectious $(\mathrm{p}=$ 0.041 ) causes and the distribution of the APACHE II prognostic score $(\mathrm{p}=0.002)$ were significantly related to high serum lactate levels and the highest probability of death in the ICU. A good association was also observed in patients who required hemodynamic support $(\mathrm{p}=0.008)$ and mechanical ventilation $(\mathrm{p}<0,0001)$.

The median serum lactate was $2.1 \mathrm{mmol} / \mathrm{l}$ (RIQ 1.4-4.2 mmol / 1). Table 2 shows the analytical values and physiological variables in the first 6 hours after admission to the ICU. It was found that the distribution of serum lactate was higher in the group of patients who presented high creatinine levels while the mean blood pressure was lower in that group, with a statistically significant relationship in relation to mortality in the ICU.

When the analysis of the Kaplan-Meier curve was performed (figure 1), patients who presented serum lactate $\leq 2 \mathrm{mmol} / \mathrm{l}$ had a higher probability of survival with a median stay of 14 days in the ICU, which 
Table 1. General characteristics of the population, stratified according to serum lactate values in the first six hours after admission to the ICU.

\begin{tabular}{|c|c|c|c|}
\hline Variable & $\begin{array}{l}\text { Serum lactate }>2 \mathrm{mmol} / \mathrm{l} \\
(\mathrm{N}=\mathbf{8 0})\end{array}$ & $\begin{array}{l}\text { Serum lactate } \leq 2 \mathrm{mmol} / / \\
(\mathrm{N}=65)\end{array}$ & $\mathbf{P}$ \\
\hline Age, average (SD) & $53,9(16,8)$ & $45,1(17,6)$ & 0,203 \\
\hline $\begin{array}{l}\text { Sex, n (\%) } \\
\text { Male } \\
\text { Female }\end{array}$ & $\begin{array}{l}46(57,5) \\
34(42,5)\end{array}$ & $\begin{array}{l}26(40,0) \\
39(60,0)\end{array}$ & 0,860 \\
\hline Apache II, median (IQR **) & $14(11,0-20,0)$ & $8(5,0-13,0)$ & 0,002 \\
\hline SOFA, median (IQR **) & $10,5(6,0-15,0)$ & $5(1,5-8,0)$ & 0,098 \\
\hline $\begin{array}{l}\text { Cause of admission to the ICU, } \mathrm{n} \text { (\% } \\
\text { Cardiovascular } \\
\text { Pulmonary } \\
\text { Neurological } \\
\text { Traumatic } \\
\text { Infectious } \\
\text { Gastrointestinal } \\
\text { Poisoning } \\
\text { Other }\end{array}$ & $\begin{array}{c}8(10,0) \\
6(7,5) \\
6(7,5) \\
26(32,5) \\
16(20,0) \\
8(10,0) \\
1(1,3) \\
9(11,3)\end{array}$ & $\begin{array}{c}1(1,5) \\
7(10,8) \\
5(7,7) \\
19(29,2) \\
11(16,9) \\
8(12,3) \\
4(6,2) \\
10(15,4)\end{array}$ & $\begin{array}{c}0,520 \\
0,463 \\
0,691 \\
0,05 \\
0,041 \\
0,738 \\
0,583 \\
0,124\end{array}$ \\
\hline Hemodynamic support, n (\%) & $14(17,5)$ & $4(6,2)$ & 0,008 \\
\hline Use Mechanical Ventilation, n (\%) & $25(31,3)$ & $21(32,3)$ & $<0,0001$ \\
\hline Stay in ICU, median (IQR **) & $5,0(4,0-7,0)$ & $6,0(4,0-7,5)$ & 0,756 \\
\hline
\end{tabular}

Table 2. Analytical values and physiological variables in the first six hours after admission to the ICU.

\begin{tabular}{|c|c|c|c|}
\hline Variable & $\begin{array}{l}\text { Serum lactate } \\
>2 \mathrm{mmol} / \mathrm{l} \\
(\mathrm{N}=80)\end{array}$ & $\begin{array}{c}\text { Serum lactate } \\
\leq 2 \mathrm{mmol} / \mathrm{l} \\
(\mathrm{N}=65)\end{array}$ & $\mathbf{P}$ \\
\hline Leukocytes / mm3, median (IQR **) & $12,5(8,7-18,9)$ & $11,6(8,5-14,3)$ & 0,055 \\
\hline Hematocrit (\%), median (IQR **) & $31,2(5,8)$ & $32(8,3)$ & 0,482 \\
\hline Platelet count / mm3, median (IQR $\left.{ }^{* *}\right)$ & $200(164,3-279,0)$ & $200(170,0-239,0)$ & 0,510 \\
\hline Blood Glucose $(\mathrm{mmol} / \mathrm{l})$, median $\left(\mathrm{IQR}{ }^{* *}\right)$ & $7,2(5,9-8,9)$ & $6,8(58,7-9,6)$ & 0,066 \\
\hline Aminotransferase Aspartate $(\mathrm{u} / \mathrm{l})$, median $\left(\mathrm{IQR}{ }^{* *}\right)$ & $42,5(29,3-75,6)$ & $41,0(31,5-69,5)$ & 0,469 \\
\hline Aminotransferase Alanine $(\mathrm{u} / \mathrm{I})$, median (IQR $\left.{ }^{* *}\right)$ & $40,0(28,3-60,0)$ & $40,0(29,0-58,0)$ & 0,124 \\
\hline Albumin $(\mathrm{g} / \mathrm{I})$, median $(\mathrm{IQR} * *)$ & $33,0(27,3-37,0)$ & $35,0(28,0-38,0)$ & 0,164 \\
\hline Creatinine $(\mathrm{Mmol} / \mathrm{I})$, median $\left(\mathrm{IQR}{ }^{* *}\right)$ & $90,5(66,3-129,5)$ & $86(68,5-114,0)$ & 0,044 \\
\hline $\mathrm{PH}$, median $(\mathrm{IQR} * *)$ & $7,41(7,35-7,45)$ & $7,42(7,37-7,45)$ & 0,225 \\
\hline PCO2 $(\mathrm{mmHg})$, median $(\mathrm{IQR} * *)$ & $35,3(21,1-42,8)$ & $35,0(30,1-42,6)$ & 0,08 \\
\hline PO2 $(\mathrm{mmHg})$, median (IQR $\left.{ }^{* *}\right)$ & $86,5(70,0-115,3)$ & $90,0(72,9-115,0)$ & 0,175 \\
\hline Base Excess, median (IQR **) & $-0,7(-4,1-2,6)$ & $-0,1(-3,6-2,2)$ & 0,341 \\
\hline Bicarbonate, median (IQR $* *)$ & $23,4(20,9-26,0)$ & $24,0(19,9-26,3)$ & 0,407 \\
\hline $\mathrm{PO} 2$ / FiO2, average $\left(\mathrm{SD}^{*}\right)$ & $306,9(137,8)$ & $341,5(117,9)$ & 0,232 \\
\hline $\mathrm{D}(\mathrm{A}-\mathrm{a}) \mathrm{O} 2$, median $(\mathrm{IQR} * *)$ & $81,0(29,2-140,6)$ & $56,6(17,5-97,7)$ & 0,241 \\
\hline Sodium (mmol / I), median (IQR **) & $136,0(132,0-141,0)$ & $133,0(130,0-138,5)$ & 0,056 \\
\hline Potassium (mmol / I), median (IQR **) & $3,8(3,4-4,2)$ & $3,7(3,4-4,2)$ & 0,845 \\
\hline Heart Rate $(\mathrm{bpm})$, average $\left(\mathrm{SD}{ }^{*}\right)$ & $93,9(21,0)$ & $97,3(18,5)$ & 0,374 \\
\hline Respiratory rate $(\mathrm{rpm})$, median (IQR $\left.{ }^{* *}\right)$ & $22,0(19,0-25,8)$ & $21,0(20,0-25,0)$ & 0,252 \\
\hline Medium Arterial Tension $(\mathrm{mmHg})$, median (IQR $\left.{ }^{* *}\right)$ & $92,3(82,1-99,8)$ & $93(80,5-102,2)$ & 0,021 \\
\hline
\end{tabular}




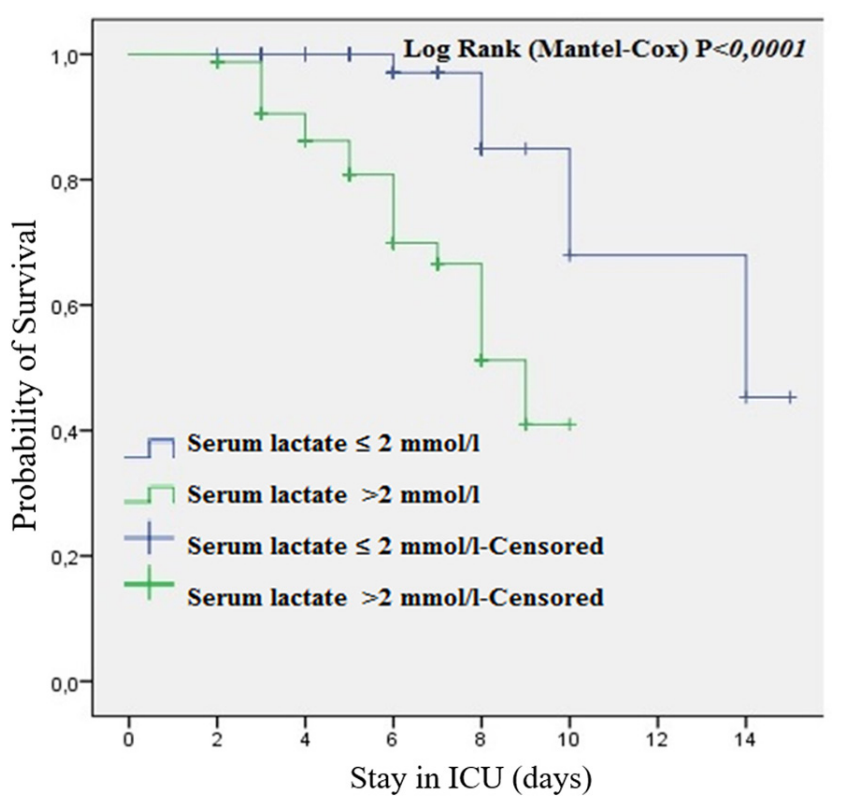

Fig. 1. Kaplan-Meier curve for the probability of survival in patients admitted to the ICU concerning serum lactate levels.

revealed a statistically significant difference in relationship to the group of patients who presented elevated serum lactate with a Log Rank (Mantel-Cox) (p $<0.0001)$.

In the Cox regression analysis (Table 3), of all the variables studied, only serum lactate was an independent predictor of mortality with a statistically significant relationship (AHR 1.28 [1.07-1.53], p = 0.008).

\section{DISCUSSION}

In every patient, but especially in the critically ill patient, a doctor has to establish a diagnosis, determine the severity of the disease, decide on a treatment, predict and monitor the degree of response in order to make all necessary adjustments before the critical condition take the patient to the point of no return. To achieve this, it is essential to have a biomarker as an aid to treatment planning in those critical moments. Serum lactate levels have been proposed as a useful tool in such situations [4].
In critically ill patients, elevated serum lactate levels at the time of admission to the hospital as a static value over time are related to higher mortality. In 2010, Soliman et al studied the lactate levels of 433 patients of a medical-surgical ICU defining hyperlactatemia as a serum concentration greater than or equal to 2 $\mathrm{mEq} / \mathrm{L} 45 \%$ of the patients had hyperlactatemia and found a direct relationship between lactate levels and risk of death, reaching a mortality of $17 \%$ with lactate concentrations between $2-4 \mathrm{mEq} / 1$ and $64 \%$ in those with concentrations greater than $8 \mathrm{mEq} / \mathrm{l}$. Also, it was correlated with a longer hospital stay in the ICU and higher APACHE II and SOFA scores $[4,8]$. The same results were found in the present study, in which the median Apache II score was 14 points in patients with serum lactate greater than $2 \mathrm{mmol} / \mathrm{l}$, obtaining a powerful association between this group of patients and the probability of death in ICU.

At present, it is proposed that in the patient with polytrauma, serum lactate levels rise not only due to the hemodynamic instability that arises as a result of circulatory shock, but also due to the trauma caused by an increase in stimulation of $\beta 2$ receptors, big producers of adrenaline. All this leads to an increase in pyruvate that saturates the capacity of the enzyme pyruvate dehydrogenase, which causes the metabolism to deviate and produce an increase in lactate levels.[5].

A previous study on traumatized patients showed that an initial lactate level of more than $4 \mathrm{mmol} / \mathrm{L}$ is associated with an increase in the probability of death in the acute phase [9]. Zachary et al. retrospectively evaluated lactate levels in patients with closed or open trauma, at least twice in the first twenty-four hours of admission [10]. The recorded mortality was $7.3 \%$. The average initial lactate levels of the survivors were lower than the deceased, with a statistically significant difference [10]. In a recent study at the San Vicente Foundation University Hospital (Medellin, Colombia), 251 polytrauma patients were evaluated, who were given lactate measures at admission, at 6 and 24 hours, $15.5 \%$ died, serum lactate upon admission was $4.6 \mathrm{mmol} /$ $\mathrm{L}(\mathrm{IQR}=2.9-6.9)$ and an important association with

Table 3. Results of the Cox regression analysis.

\begin{tabular}{lccc} 
Variable & AHR & $\mathbf{9 5 \%}$ IC & P \\
Serum lactate & 1,28 & $1,07-1,53$ & 0,008 \\
APACHE II & 1,07 & $1,00-1,14$ & 0,06 \\
SOFA & 0,96 & $0,89-1,03$ & 0,258 \\
Excess Base & 1,02 & $0,97-1,07$ & 0,417 \\
\hline AHR, adjust & .
\end{tabular}


Available online at: www.jccm.ro

mortality was found in the adjusted logistic regression model [11]. In our study, traumatic causes and serum lactate greater than $2 \mathrm{mmol} / \mathrm{l}$ were significantly related to death in the ICU.

According to world literature, there are multiple reports that show the relationship between the elevation of serum lactate and the occurrence of septic states $[6,12-15]$, this is due to the presence of an imbalance between the genesis and clearance of serum lactate. It is proposed that there is a state of critical tissue hypoperfusion that affects the synthesis of ATP by blocking the pyruvate dehydrogenase enzyme due to hypoxia this, in turn, alters with the conversion of pyruvate to lactate [16]. In one study, 830 patients admitted to an emergency ward, with a diagnosis of severe sepsis, were classified into three groups according to the level of lactate in low risk. The three groups were defined as; a level of lactate less than 2; intermediate from 2 to 3.9 and high greater than 4 . At twenty-eight post-admission days, mortality was of $15.4 \%, 37 \%$ and $46.9 \%$, respectively for the three defined lactate levels. In contrast, in patients who did not present with shock, mortality was $8.7 \%, 16.4 \%$ and $31.8 \%$, respectively [4].

Our results concur with the literature, since the cause of admission of infectious origin, and the presence of elevated serum lactate levels showed a significant relationship with mortality in the ICU.

Concerning the need for mechanical ventilation, hemodynamic support and presence of arterial hypotension, in the present study, an association with hyperlactatemia and death in ICU was also found. Despite the effect that mechanical ventilation has on cardiac output and tissue perfusion, this alone did not influence the elevated levels of serum lactate. It is concluded that the cause may be related to the fact that many of these patients presented in a state of shock, with hemodynamic instability and need for support with vasoactive amines, which in turn results in a decreased blood flow to the tissues, favouring anaerobic metabolism, with lactic acidosis and hyperlactatemia.

Concerning the ICU survival time, patients who presented high serum lactate levels died more quickly than those who presented normal parameters, with significant statistical differences between both groups of studies (figure 1). On the other hand, in the Cox regression analysis, serum lactate levels were only associated with an increased risk of dying in the ICU (AHR 1.28 [1.07-1.53], $\mathrm{p}=0.008)$.
The Journal of Critical Care Medicine 2020;6(1) • 63

It is accepted that observational studies such as the present one, do not allow stratified randomization. The study was restricted to one ICU, but never the less addressed an ICU population with diverse medical, surgical, traumatic and infectious conditions, which we feel moderates its limitations.

\section{- CONCLUSIONS}

The assessment of a critically ill patient by determining serum lactate levels provides useful and valuable information. Its measurement is not expensive, it is fast, and it is available.

\section{DEFERENCE}

1. Cajas Santana LJ. Correlación entre Apache IV, Apache II y el mayor nivel de lactato en las primeras 24 horas en la predicción de mortalidad en Pacientes de la Unidad de Cuidado Intensivo de la Fundación San Carlos/Correlation between Apache IV, Apache II and the highest level of lactate measure in the first 24 hours for mortality prediction among Patients in the Intensive Care Unit of San Carlos Foundation: Universidad Nacional de Colombia; 2012.

2. Rivera Alejandro. Validación de scores pronósticos (SOFA, APACHE II y TRISS) en la Unidad de Cuidados Intensivos, del Hospital Escuela Antonio Lenin Fonseca, Agosto 2009 - Julio 2010, Pág. 910.

3. Duarte Matus PL. Lactato inicial como biomarcador de estratificación de riesgo en pacientes ingresadas a la unidad de cuidados intensivos del Hospital Bertha Calderon Roque Septiembre-Noviembre 2015: Universidad Nacional Autonóma de Nicaragua, Managua; 2016.

4. Dueñas C, Ortíz G, Mendoza R, Montes L. El papel del lactato en cuidado intensivo. Revista Chilena de Medicina Intensiva. 2016;31(1):13-22.

5. Bermúdez-Rengifo WA, Fonseca-Ruiz NJ. Utilidad del lactato en el paciente críticamente enfermo. Acta Colombiana de Cuidado Intensivo. 2016;16(2):80-9.

6. Benítez JT. Valor del lactato sérico como factor pronóstico de mortalidad en pacientes con sepsis. Revista Virtual de la Sociedad Paraguaya de Medicina Interna. 2017;4(2):11-8.

7. Freitas $A D$, Franzon $O$. Lactate as predictor of mortality in polytrauma. ABCD Arquivos Brasileiros de Cirurgia Digestiva (São Paulo). 2015;28(3):163-6.

8. Soliman $\mathrm{H}$, Vincent J-L. Prognostic value of admission serum lactate concentrations in intensive care unit patients. Acta Clinica Belgica. 2010;65(3):176-81.

9. Pineda-Garcés DC, González-Urhan $\mathrm{M}$, Morales-Uribe $\mathrm{CH}$. Aclaramiento de lactato en trauma penetrante grave. Revista Colombiana de Cirugía. 2018;33(4):380-9.

10. Dezman Z, Comer AC, Smith G, Hu PF, Mackenzie CF, Scaleaet 
64 - The Journal of Critical Care Medicine 2020;6(1)

TM, et al. Repeat lactate level predicts mortality better than rate of clearance. Am J Emerg Med. 2018;1-5. doi: 10.1016/j. ajem.2018.03.012

11. Morales C, Ascuntar J, Londoño JM, Niño CD, León JP, Bernal $E$, et al. Lactate clearance: prognostic mortality marker in trauma patients. Revista Colombiana de Anestesiología. 2019;47(1):41-8.

12. Sulla Anco G. Niveles de lactato serico e indice de choque como predictores de mortalidad en pacientes con sepsis severa y/o shock septico en la unidad de shock trauma adultos del hospital nacional Sergio E. Bernales Lima de Enero a Diciembre del 2013.

13. Noches Buelvas AC, Martínez A, Fernando E. Correlación de las mediciones y aclaramiento del lactato arterial entre las 6
Available online at: www.jccm.ro

y 72 horas con la mortalidad en pacientes con sepsis severa y/o choque séptico en 3 Hospitales de Bogotá: Universidad Nacional de Colombia-Sede Bogotá 2017.

14. Huarcaya Mescua CN. Depuración de lactato como marcador pronóstico en sepsis severa y choque séptico. Hospital Nacional Sergio E. Bernales 2016-2017. 2017.

15. Londoño J, León $A L$, Rodríguez $F$, Barrera $L$, de la Rosa $G$, Dennis $R$, et al. Lactato sérico en urgencias como factor pronóstico en pacientes con sepsis sin hipotensión. Medicina Clínica. 2013;141(6):246-51.

16. Vásquez-Tirado GA, García-Tello AV, Evangelista Montoya FE. Utilidad del lactato sérico elevado como factor pronóstico de muerte en sepsis severa. Horizonte Médico. 2015;15(2):3540. 